\title{
JUURNAL_RU
}

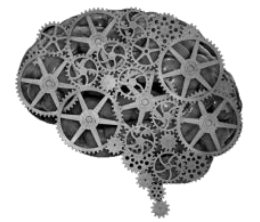

COMPANY GROUP "INTELLEKT"

\author{
Быч Е.И. \\ Финансовый университет при Правительстве РФ \\ Москва, Россия
}

doi: 10.18411/lj2016-6-3-01

\section{Деловая игра в обучении профессиональному иноязычному общению}

В статье идет речь о таком методе как деловая игра, ее роли при формировании профессиональных компетенций, раскрываются ее основные достоинства и недостатки. Приводится краткое содержание деловой игры “Переговоры”, составленной на основе известной игры Р.Кийосаки “Денежный поток".

Ключевые слова: деловая игра, познавательная активность, коммуникативная компетенция, коммуникативный метод, самостоятельность студента.

Современный мир характеризуется усилением конкуренции, что ведет к изменению требований к подготовке выпускников высшей школы, возникновению необходимости модернизации учебного процесса.

Поскольку обучение английскому языку будущих специалистов ориентировано на приобретение навыков и умений профессионального общения, то наиболее эффективной технологией обучения, позволяющим решать поставленные задачи, нам представляется деловая игра. Игровая методика при обучении иностранному языку всегда активно использовалась на всех уровнях образования, для всех возрастных категорий и с различными образовательными целями.

В наше время образование развивается в условиях информационного общества, поэтому игра принимает формы игрового моделирования, включая 
цифровое моделирование, электронное обучение, обучение с помощью компьютера, подкастинг, т.е. технология, сочетающая в себе использование мультимедиа, иноязычных онлайн ресурсов, проектное обучение, которые служат максимальному эффекту "симуляции", т.е. моделирования реальных ситуаций и контекстов профессионального общения. В деловой игре в условиях совместной работы каждый обучающийся приобретает навыки ведения бизнеса на иностранном языке, социального взаимодействия. Студенты учатся преодолевать языковой барьер в ходе ведения деловых переговоров, показывают более глубокий интерес к изучению иностранного языка. Таким образом, в достижении таких целей обучения и воспитания деловая игра обладает наибольшими возможностями.

Отличие деловой игры от традиционных методов обучения, ее обучающие возможности заключаются в том, что в ней воссоздаются основные закономерности движения деятельности и мышления специалиста на материале учебных ситуаций, порождаемых и разрешаемых совместными усилиями студентов.

Преподаватель должен создать такие условия, чтобы студенты, участники деловой игры на иностранном языке, могли реализовать комплекс умений, приобретенных в рамках других форм обучения на предшествующих игре этапах. К основным таким умениям можно отнести следующие: воспринимать профессиональную ситуацию как целостную модель, уметь анализировать составляющие объекта деятельности и условия его функционирования, выделять в этой ситуации предмет действий, цель, средства и ожидаемые результаты преобразования ситуации, формировать и ставить задачу, выделять систему вербальных и невербальных действий, обеспечивающих достижение цели в данных условиях, осуществлять действия по решению профессиональной задачи, проводить оценку и обобщение полученных результатов, доказывать правильность решения. 
Деловая игра на английском языке мобилизует резервы умственной деятельности и повышает иноязычную познавательную деятельность, так как, с одной стороны, усиливает познавательно-оценочное восприятие информации, а с другой - восполняет пробелы в имеющейся информации за счет комплексного видения тех проблем, которые возникают в процессе игры.

Деловая игра характеризуется следующими общими чертами:

- жизненность и типичность конкретных ситуаций, которые рассматриваются в деловых играх, наличие обстановки, в условиях которой необходимо проводить анализ проблемной ситуации и принимать решения;

- отсутствие полной информации, принятие решения в условиях неопределенности, риска или даже противодействия;

- динамичность процесса управления, возможность влияния принятых ранее решений на изменение обстановки в последующие моменты;

- наличие действующих лиц в системе управления: игроков, исполняющих роли должностных лиц, игроков - экспертов и игроков- организаторов, готовящих материалы для деловой игры, представляющих информацию и направляющих процесс игры;

- наличие правил и регламентации игры.

Одним из эффективных путей формирования коммуникативной компетенции посредством активизации обучения является технология деловых игр, позволяющая непосредственно включить процесс обучения иностранному языку в модель будущей трудовой деятельности студентов. Основные интересы обучаемых неязыкового профиля находятся именно в сфере их специальности, и они чаще всего рассматривают иностранный язык как средство расширения своих деловых контактов, профессиональных умений в профессиональнотрудовой сфере. 
Технология деловых игр, направленная на обучение профессиональному общению, имеет ряд особенностей.

1. Деловая игра должна базироваться на речевом материале, отражающем конкретную ситуацию общения в профессиональнотрудовой сфере.

2. В деловой игре преобладает момент самообучения над обучением. Это происходит потому, что преподаватель иностранного языка некомпетентен в вопросах специальности обучаемых. Поэтому обучаемые могут быть привлечены как к составлению деловой игры, так и к оценке ее по параметру: достигнута коммуникативная цель или нет. Участие студентов в организации и проведении деловой игры активизирует их мыслительную деятельность, повышает их творческую активность, так как позволяет им в реальности применять знания иностранного языка. Достижение успеха в игре зависит в большей степени от знания иностранного языка как учебному предмету, способствует возникновению желания расширить свои возможности в его использовании.

3. Очень важный момент в деловой игре - ее проблемность. Большую методическую ценность представляют деловые игры, которые стимулируют возникновение все новых и новых ситуаций общения. Такие деловые игры позволяют привлечь как можно большее число студентов к участию в ней.

4. В деловой игре одними из ведущих являются принципы совместной деятельности и диалогического общения участников. В деловой игре участники самоутверждаются не только как личности, но и прежде всего, как специалисты в своей области трудовой деятельности.

5. Деловая игра предполагает взаимодействие ее участников. В этой связи можно выделить следующие типы деловых игр: играсотрудничество (например, достижение договоренности между 
российской и зарубежной фирмами о совместном строительстве завода), игра-конфликт (переговоры руководства одной компании с представителями другой компании по поводу срыва поставок нового оборудования),игра-соревнование (например, обсуждение проектов производства и сбыта какого-нибудь вида продукции конкурирующими фирмами). Каждый тип игры отличается спецификацией целей, на достижение которых направлены усилия ее участников. Конечно, многое зависит от подбора участников, от того, насколько быстро они включаются в игру. Опыт проведения деловых игр показывает, что каждая группа студентов имеет свой взгляд на одну и ту же деловую игру, находит такие оригинальные решения, которые помогают преподавателю совершенствовать игру, более точно замещать реальность условными игровыми ситуациями. Перед преподавателем всегда возникают вопросы о том, как организовать студентов, чтобы их знания, умения, навыки формировались наилучшим образом, как мотивировать студентов, как помочь студентам с более низким уровнем знания иностранного языка получить наибольшую пользу от участия в игре.

Профессиональная деятельность состоит из различных коммуникаций. Любой специалист должен иметь достаточно высокий уровень коммуникативной компетенции в устной и письменной речи, как на родном, так и на иностранном языке. В данной ситуации деловая игра рассматривается как эффективная форма обучения студентов профессиональным коммуникативным компетенциям. Применение коммуникативного метода на занятиях иностранным языком предполагает обучению общению посредством этого языка, т.е. процесс обучения является моделью процесса обучения, а успешность обучения во многом определяется степенью приближенности процесса изучения языка условиям естественного общения. 
Деловая игра наряду с другими методами обучения служит накоплению опыта профессионального и межкультурного общения, близкого к реальному. Проведение различных деловых игр на английском языке позволяет выяснить, насколько хорошо студенты знают область своей профессиональной деятельности. Например, наиболее распространенная деловая игра “Переговоры" - интеллектуальная игра, ориентированная на повышение коммуникативных навыков при обучении английскому языку студентов.

В данной статье предлагается деловая игра, основанная на известной разработке Р.Кийосаки “Денежный поток”.

Опыт проведения этой игры показывает, что для ее организации требуется тщательная подготовка:

- определяется цель игры;

- описывается игровая ситуация и формулируются правила проведения игры:

Студенты разбиваются на подгруппы. Каждая подгруппа выбирает свою страну, которая имеет в наличии свои ресурсы (представлены в таблице ниже);

Каждый раунд меняется цена на ресурсы. Их динамика расписана в таблице. Длительность каждого раунда - 5 мин. Каждая страна-участница начинает игру, имея в наличии разное количество ресурсов. Страны торгуют своими ресурсами с другими игроками с целью получения максимальной выгоды. Выигрывает страна, набравшая наибольшее количество очков. Расчет переводится на валюту. В игре может быть несколько раундов, в ходе которых меняется ситуация. В конце каждого раунда участники подсчитывают количество ресурсов. Здесь приводятся 5 раундов с примерными ситуациями:

Раунд 1.

Найдены новые месторождения нефти. Нефть понизится, все остальные ресурсы, кроме воды, повысятся на 1 единицу, а уголь - на 2 единицы.

Раунд 2. 
В Саудовской Аравии наблюдается острая нехватка питьевой воды. В итоге, все страны в рамках благотворительной помощи отдают половину имеющейся у них воды.

Введение новой технологии работы с ураном повлекло за собой увеличение его стоимости на 2 единицы.

Раунд 3.

В Европе была остановлена несанкционированная акция протеста против использования атомной энергии.

Разработка сланцевого газа потерпела фиаско. Рынок обвалился на 3 пункта. Авария на АЗС показала опасность атома для мира. Этот ресурс падает в цене на 5 единиц.

Мировой финансовый кризис привел к резкому росту инфляции. Каждая страна теряет 5 единиц;

Раунд 4.

Аналитики предсказывают истощение крупного бассейна угля. Рабочие обеспокоены возможным сокращением в этой сфере.

Произошла утечка нефти. Большой объем пресной воды был загрязнен.

Цена угля повышается на 3 единицы. Нефть обесценивается на 1 единицу. Вода повышает свои позиции на 3 очка.

Раунд 5.

Россия сокращает добычу газа на 40\%.Аналитики не могут прийти к четкому пониманию, как это отразится на цене газа в дальнейшем.

Цена на уголь опускается на 4 единицы. Китай теряет половину своих угольных запасов.

Мировой финансовый кризис повлек резкий рост инфляции. Нефть повышается в цене на 2 единицы.

- определяется система оценивания результатов игры (оценочный лист). 
Таблица ресурсов стран-участниц.

\begin{tabular}{|c|c|c|c|c|c|c|c|}
\hline Команда & газ & нефть & уголь & уран & вода & деньги & $\begin{array}{c}\text { общее } \\
\text { количество }\end{array}$ \\
\hline Япония & 0 & 0 & 0 & 7 & 2 & 13 & 52 \\
\hline Америка & 4 & 4 & 0 & 2 & 2 & 15 & 50 \\
\hline Ватикан & 1 & 1 & 1 & 1 & 1 & 46 & 19 \\
\hline Австралия & 0 & 3 & 10 & 3 & 4 & 5 & 60 \\
\hline Китай & 4 & 3 & 25 & 0 & 0 & 16 & 49 \\
\hline Саудовская Аравия & 5 & 10 & 0 & 0 & 0 & 10 & 55 \\
\hline Ресурсы, общее & 14 & 21 & 36 & 13 & 9 & 105 & 65 \\
\hline Цена & 3 & 4 & 1 & 6 & 5 & & \\
\hline
\end{tabular}

В процессе проведения деловой игры:

- отрабатываются различные профессиональные действия студентов;

- значительно активизируются междисциплинарные связи;

- реализуется творческий потенциал студентов;

- преобладает доля групповой и парной деятельности студентов;

- формируется умение студентов работать в команде;

- студенты учатся самостоятельно организовывать свою деятельность;

- повышается мотивация студентов к освоению будущей профессии;

- растет самооценка студентов;

- занятие проходит в обстановке состязательности;

- преподавателю легче обнаружить пробелы в базовых знаниях студентов и, следовательно, внести коррективы в преподавание дисциплины на последующих этапах.

В конце игры подводятся итоги и оценивается степень формирования ряда компетенций:

- организовывать собственную деятельность;

- принимать решения в стандартных и нестандартных ситуациях и нести за них ответственность; 
- анализировать и оценивать информацию;

- работать в коллективе и команде;

- брать на себя ответственность за работу членов команды и результат выполнения заданий;

Критерием оценки формирования профессиональных компетенций является количество набранных баллов. Итоговая оценка зависит от количества набранных баллов.

Деловая игра, как средство обучения, таит в себе значительные потенциальные возможности. Но именно потенциальные, так как для реализации поставленных задач в деле достижения высоких результатов обучения студентов на уровне мировых стандартов, необходимо не только желание и творческое отношение преподавателя к использованию деловой игры, но и тщательная длительная подготовительная работа, правильный подбор пропорционального соотношения игровых форм и традиционных способов обучения.

Использование деловых игр при обучении экономическим дисциплинам тем более ценно, что профессиональная деятельность специалистов экономического профиля носит достаточно многообразный характер, и применение деловых игр в подготовке специалистов в области экономики поможет активизировать процесс обучения и связать его с будущей профессиональной деятельностью.

Знания и опыт, полученные в деловых играх, могут быть более значимыми и полезными по сравнению со знаниями и опытом, полученными в ходе обучения или даже в ходе в профессиональной деятельности. Причиной этого является прежде то, что деловая игра позволяет, во-первых ,увеличить масштаб рассматриваемой действительности, во-вторых, деловая игра наглядно помогает представить последствия принятых решений и дает возможность найти и проверить в действии другие решения. 


\section{Литература:}

1. Белокопытов Ю., Панасенко Г. Активные методы обучения // Высшее образование в России. - 2004. - № 5. - С. 168.

2. Вербицкий А.А. Деловая игра как метод активного учения//”Современная высшая школа".-2005.-№3.-С.23-28.

3. Дудченко В.С. Инновационные игры. Практика, методология, теория. - М.: Кватро-Принт, 2007. - 110 с.

4. Платов В.Я. Деловые игры: разработка, организация, проведение. М.,1991.

5. Яруллина Л.Р. Использование активных методов обучения в высшей школе // Вестник ТИСБИ. - 2008. - № 1. - С. 12-19.

6. Методы активного обучения // Википедия. 2014. URL: http://ru.wikipedia.org/wiki.

7. Деловая игра - описание метода // ПСИ-ФАКТОР. 2014. URL: http://psyfactor.org/lib/igra2.htm 